\title{
Development and validation of an interactive educational technology on spotted fever*
}

\author{
Gabriela Rodrigues Bragagnollo 1,2 \\ (D) https://orcid.org/0000-0003-1480-8046 \\ Rosangela Andrade Aukar de Camargo ${ }^{1}$ \\ (D) https://orcid.org/0000-0002-4872-2331 \\ Marcela das Neves Guimarães ${ }^{3}$ \\ (D) https://orcid.org/0000-0003-2008-0119 \\ Tâmyssa Simões dos Santos ${ }^{3}$ \\ (D) https://orcid.org/0000-0002-7911-0389 \\ Estela Leite Meirelles Monteiro 4 \\ (1) https://orcid.org/0000-0002-5736-0133 \\ Beatriz Rossetti Ferreira ${ }^{1}$ \\ (D) https://orcid.org/0000-0002-6781-2236
}

\footnotetext{
* This article refers to the call "Educational technologies and innovative teaching methods in the training of human resources in health". Paper extracted from doctoral dissertation "Development of educational technology on Macular Fever for health education", presented to Universidade de São Paulo, Escola de Enfermagem de Ribeirão Preto, PAHO/WHO Collaborating Centre for Nursing Research Development, Ribeirão Preto, SP, Brazil. Supported by Conselho Nacional de Desenvolvimento Científico e Tecnológico (CNPq), Grant \# 830700/1999-4, Brazil.

1 Universidade de São Paulo, Escola de Enfermagem de Ribeirão Preto, PAHO/WHO Collaborating Centre for Nursing Research Development, Ribeirão Preto, SP, Brazil.

2 Scholarship holder at the Fundação de Amparo à Pesquisa do Estado de São Paulo (FAPESP), Brazil.

${ }^{3}$ Centro Universitário Maurício de Nassau, Curso de Enfermagem, Maceió, AL, Brazil.

${ }^{4}$ Universidade Federal de Pernambuco, Recife, PE, Brazil.
}

Objective: to develop and validate an interactive educational technology on spotted fever, to offer an innovative teaching method. Method: a methodological study that covered the following stages: analysis and diagnosis; instructional planning, didactic design, review, and validation and production of technology. Results: the analysis and diagnosis were obtained from experiences in education and health activities for spotted fever. In the instructional planning, it was defined that the technology would be presented in the form of an Interactive Laboratory, with learning stations. The production of the Laboratory was carried out by a multidisciplinary team made up of a carpenter, an electrician, and a plastic artist, among others. The review and validation process was subdivided into two stages: appearance and content validation by professionals in the fields of biology, and education and semantic validation by students of the Nursing and Pedagogy courses. The results of the appearance and content validation showed a content validity index over 0.8 for the vast majority of the variables. In the semantic validation, the Laboratory was evaluated positively by the students. Conclusion: the trajectory followed for the construction of the Interactive Laboratory on spotted fever gave academic and scientific support to the product, offering an innovative educational resource with pedagogical potential that values significant learning.

Descriptors: Rocky Mountain Spotted Fever; Health Education; Educational Technology; Association Learning; Teaching Materials; Epidemiology.

\section{How to cite this article}

Bragagnollo GR, Camargo RAA, Guimarães MN, Santos TS, Monteiro ELM, Ferreira BR. Development and validation of an interactive educational technology on spotted fever. Rev. Latino-Am. Enfermagem. 2020;28:e3375. [Access ; Available in: DOI: http://dx.doi.org/10.1590/1518-8345.3678.3375. 


\section{Introduction}

Spotted Fever (SF) is an emerging zoonosis with high lethality, which has presented itself as a new challenge for public health, since its incidence and prevalence have increased in a worrying way in the last 10 years in Brazil and worldwide. This increase was possibly due to the disease having urbanized, and being no longer limited to rural and forest regions ${ }^{(1-5)}$.

Brazilian SF is an infectious disease caused by the Rickettsia rickettsii bacterium, transmitted to man through the bite of the infected Amblyomma spp tick. The tick phases that most affect humans are larvae and nymphs, popularly known as micuins and red, which are difficult to visualize and perceive ${ }^{(6)}$. Capybaras have notoriety in the epidemiological chain of the disease, as they are the main reservoirs of the bacteria, in addition to being hosts for SF transmitting ticks(7). The occupation of areas with riparian forests by man brought him closer to the capybaras, which created a favorable environment for the infestation of man by the tick and transmission of the disease ${ }^{(2)}$.

From 2007 to 2017, in Brazil 1,572 cases of SF were confirmed, of which 534 died, adding up to a lethality rate of approximately $34 \%$. The southeastern region of the country has the largest number of cases (980), of which 795 were reported in the State of São Paulo, with 424 deaths $^{(8)}$. In 2018 the state of São Paulo added an alarming number of 103 cases, of which $49 \operatorname{died}^{(9)}$.

As already described, SF is not a disease restricted to Brazil, including other countries in Latin America, such as Colombia, Argentina, and Mexico, which have also registered an increase in the number of cases of the disease. In Argentina, the lethality rate is even higher than in Brazil, being between $40 \%$ of the diagnosed cases $^{(10)}$. In Colombia, a study found that, in 2015, the cumulative incidence of infection for the disease reached $6.23 \%$, but this incidence may be even higher due to SF being considered a neglected disease, sometimes underreported when confused with other febrile illnesses ${ }^{(11)}$. A serious mistake, considering that, if SF is not diagnosed and treated in a timely manner, it evolves to death in a few days ${ }^{(11-13)}$. In Mexico, the significant increase in the incidence of SF in 2015 led the country to declare an epidemiological emergency to contain the cases $^{(14)}$.

In the United States, SF is also a public health problem, and its incidence went from 1.7 cases per 1 million people in 2000 to 13.2 cases per million in $2016^{(15)}$. In the $2004-2016$ period, 650,000 cases of vector-borne diseases were reported, of which $75 \%$ were caused by ticks ${ }^{(16)}$.
In order to reduce the problem, the Ministry of Health in Brazil adopted a strategy to identify environments with potential risk for the presence of SF and offered technical training to professionals in the Unified Health System network in these regions ${ }^{(17)}$. To this end, it implemented instructional materials in the format of video lessons on actions of epidemiological and environmental surveillance ${ }^{(18)}$. Unfortunately, these actions were not satisfactory, since the prevalence of the disease is still frequent, which stimulates the development of new actions for preventive education of the population. In fact, one of the gaps observed on the topic in the bibliographic review was the absence of educational materials on the theme, as well as educational interventions in health.

On an ongoing basis, researchers have revealed that health education cannot be limited to just activities that address the transmission of information, since the process of learning demands the construction of strategies in which the didactic and pedagogical aspects meet the cultural dimensions, psychosocial, economic, and political aspects of a given community ${ }^{(19-20)}$. In this sense, when planning health education actions, the researcher needs to recognize the context to detect the factors that may contribute or hinder its development, with the transmission of information being only part of the process ${ }^{(21)}$. The population needs to recognize the need for actions so that they are incorporated into their daily lives, in order to improve the public health scenario in Brazil(22),

In the planning of health education projects, the construction of educational technologies (ETs) that take into account the aforementioned aspects is crucial for the teaching-learning process ${ }^{(23)}$. An ET consists of a systematic set of scientific knowledge that allows planning and execution in order to control, monitor, and evaluate the educational process, so as to interrelate with knowledge and autonomy ${ }^{(24)}$, allowing the individual to live new experiences(25).

It is worth mentioning that the construction of an ET requires the preparation of the educator, in order to understand the elements that make up the teachinglearning process, in addition to genuine respect for the protagonism of the student, arousing curiosity to increase their awareness of the world(24,26). In this perspective, this study was based on Ausubel's theory of meaningful learning, which values students' prior knowledge in order to build and reconstruct knowledge based on pleasant and effective learning(27-28).

In this way, a learning environment, based on this theory, seeks to create diverse learning situations with encouragement to interactive learning. For this, it is necessary that the didactic material is potentially 
significant, to actually involve the student in the understanding of important concepts. In this process, it is crucial to value the students' previous knowledge, based on their critical and creative thinking, which provides the integration of existing knowledge with the new one (27-28). $^{2}$.

The current study aimed to develop and validate an interactive ET on SF to offer an innovative teaching method.

\section{Method}

This was a methodological study(29), based on the stages proposed by $\mathrm{Abreu}^{(30)}$ : planning (analysis and diagnosis and instructional planning), production (didactic design and review and validation), implementation and evaluation (evaluation). Here, we will present the planning and production stages. The implementation and evaluation of the ET was planned to be carried out in the future.

The analysis and diagnostic evaluation of this study was based on results obtained in a previous extension project, entitled "Spotted Fever: What do I have to do with this?", offered at USP Campus Units in Ribeirão Preto: Center for Physical Education, Sports and Recreation; Ribeirão Preto Nursing School (Escola de Enfermagem Ribeirão Preto - EERP) and at the University Restaurant( ${ }^{(31)}$.

The results apprehended in the extension project were expanded by a literature review, with the following guiding question: What knowledge is needed to encourage prophylaxis for SF?

The electronic databases selected for the searches were the US National Library of Medicine/Medical Literature Analysis and Retrieval System Online (PubMed/MEDLINE), Web of Science, Science Direct, Cumulative Index to Nursing and Allied Health Literature (CINAHL), Scientific Electronic Library Online (SCiELO), Latin American and Caribbean Literature in Health Sciences (Literatura LatinoAmericana e do Caribe em Ciências da Saúde, LILACS), and the Nursing Database (Base de Dados em Enfermagem, BDENF), the latter two being indexed in the Virtual Health Library (VHL).

To conduct the search, we used the descriptors indexed in the Health Sciences Descriptors (Descritores em Ciências da Saúde, DeCS), in Portuguese and Spanish, and descriptors indexed in the Medical Subject Headings (MeSH) for the English language. It is noteworthy that, in PubMed/MEDLINE, Science Direct, Web of Science, and CINAHL we obtained results only with descriptors in English.

The descriptors "Rocky Mountain Spotted Fever", "Health promotion", "Prevention", "Health education",
"Lyme Disease", "Fiebre Maculosa de las montañas rocosas", "Promoción de la salud", "Prevención", "Educación en salud", "Enfermedad de Lyme", "Febre maculosa das montanhas rochosas", "Prevenção", "Promoção da saúde", "Educação em saúde", and "Doença de Lyme" were crossed by the boolean operators "AND" and "AND NOT" in different ways for the maximum production related to the theme.

To compose the list of articles, studies were selected that presented at least one descriptor related to SF and that met the following filter criteria: available in full, database, language, year of publication (2006-2016), and type of document (scientific articles only).

13 searches were carried out, of which 7 (seven) were conducted with combined descriptors and 6 (six) with a single descriptor, with a total of 26 articles selected. The consultation of the literature allowed updating and constructing knowledge on the theme and required reflection on the selection of content to give credibility to the information that would be included in order to fill the knowledge gap of the participants, with an appreciation of the advancement of science on the theme of SF.

The information obtained from the review supported instructional planning, in which the objectives, method, strategies, and specifications of the resources necessary to build the ET were detailed, as well as the content and its sequence ${ }^{(32)}$. The review also contributed to the development of the didactic design of ET on SF, when it was defined that it would be presented in the form of an interactive and self-explanatory laboratory, using learning stations. Thus, the activity was set up to allow the participant to learn in an autonomous, dynamic and playful way, sharpening the use of the senses when exploring and experiencing the educational environments of each station(33-35).

The writing of the script provided a look at the final version of the $E T$, based on the didactic design ${ }^{(36)}$. A joiner, an electrician, an artist, a tailor, and a draftsman were the professionals responsible for the production of the ET, which took 9 (nine) months to be built. Subsequently, the content, strategies, and proposed activities that constituted the ET were analyzed and evaluated ${ }^{(30)}$ using a specific model(37) to validate its appearance and content. For the semantic validation, the model suggested by the DISABKIDS ${ }^{\circledR}$ group was used, which has been recognized by the scientific community ${ }^{(38)}$.

Professionals in the fields of biology and education of any age and gender, in an intentional non-probabilistic selection, made up a committee of 9 (nine) judges who carried out the validation of the ET's appearance and content. Thus, we comply with Pasquali's recommendation ${ }^{(37)}$ with an odd number of specialists 
to obtain a consistent measurement. After consulting the curriculum vitae on the Lattes Platform, those with more than 5 (five) years of training and who worked in the previously mentioned areas during the information collection period were selected(39).

For the evaluation of the ET, we elaborated an instrument based on another study related to $\mathrm{ETs}^{(40)}$, with adjustments, so that the judges were able to evaluate the objectives, content (general organization, structure, presentation, coherence, and formatting), appearance and language (signs expressing ideas and concepts); as well as the clarity, objectivity, ease and understanding of the ET. The items of this instrument were organized in a 5 (five) point Likert scale format ${ }^{(37)}$, where the judges indicated whether they fully agree (5), partially agree (4), neither agree nor disagree (3), partially disagree (2 ) or strongly disagree (1), in addition to providing a space for them to suggest changes. The participation of the judges took place by e-mail, and the instrument was sent along with a document explaining the content of each learning station, photos of it, as well as a video showing the entire ET.

For semantic validation, 8 (eight) undergraduate students from the Nursing and Pedagogy courses were selected for convenience. The number required to complete this phase, according to the DISABKIDS ${ }^{\circledR 38}$ manual, is at least 3 (three) participants for each age group and subset of items in the instrument. In the present study, as the age group was not a criterion for differentiating answers, the students were divided according to the specifics of the courses. The sample was probabilistic obtained by manual draw, in order to maintain homogeneity between groups.

The purpose of semantic validation was to ascertain, through interviews with the subjects that compose the population for which the material is intended, the level of understanding and acceptance of the terms, the relevance of the items, the existence of some difficulty, and the possible need of adaptation ${ }^{(41)}$.

Validation took place in two stages: the first evaluated the general impression on the ET in order to identify whether the contents were clear and consistent, using a general impression form. In the second stage, a specific semantic validation was performed, in which the participants analyzed a subset of items, described below.

In accordance with the guidance of the DISABKIDS $^{\circledR}$ Group $^{(38)}$, the students were subdivided into 2 (two) groups to assess the clarity, relevance, and adequacy of each item. Group A was composed of four (4) students from the first year of the Nursing course, who answered the semantic validation form (multiple choice) specific to subset $A$, composed of 4 (four) variables. In Group B, four (4) students from the first year of the Pedagogy course participated, who answered the semantic validation form (multiple choice) specific to subset $B$, also composed of 4 (four) variables. The forms used in this phase were made available by the DISABKIDS ${ }^{\circledR}$ group in Brazil $^{(42-43)}$. The limitation of four (4) variables per group is justified to avoid tiredness of the research participants.

Descriptive statistics and the Content Validity Index (CVI) were used to analyze the data of the evaluation stage by the committee of judges. The calculation for each variable was performed by dividing the sum of the agreement of the items marked with grades 4 (four) and 5 (five) by the committee of judges by the total number of items answered ${ }^{(44)}$. For semantic validation, data evaluation was also performed using descriptive statistics, by means of the Statistical Package for the Social Sciences (SPSS), version 17.0(45).

The research herein presented was approved by the Research Ethics Committee of the Ribeirão Preto Nursing School - University of São Paulo - CAAE: 57335516.6.0000.5393, following the recommendations of Resolution 466/2012 of the Ministry of Health/National Health Council(46).

\section{Results}

In the stage of diagnostic analysis of previous knowledge on the theme, 210 people attending the USP Campus of Ribeirão Preto participated, 130 people (62\%) were female and 80 (38\%) male, aged between 18 and 80 years old. The analysis of the answers obtained showed that the population's knowledge regarding SF was unsatisfactory, as only $35 \%$ of the population knew the disease, which could contribute to the risk of exposure since, in the last few years there has been an increase in the number of capybaras inhabiting the Campus, which greatly contributes to the infestation of vegetation by ticks. The identification of the knowledge gap regarding SF stimulated the production of an ET to sensitize the population about the problem and how to prevent it in that environment.

With the identification of the knowledge gap, a review of the literature was carried out to offer current material, seeking to meet the demands of the target audience, valuing the advancement of science on SF. In general, the selected articles pointed out the importance of adopting preventive and health promotion measures, seeking to encourage moments of health education in order to prevent or reduce the risks of SF. The discussions revolved around epidemiological data, incidence, and risks of the disease in specific groups, and suggested preventive measures and educational interventions to combat SF. With regard to health education strategies on the disease, we can highlight the following: 
1) Guidelines for people who live in or visit tick-infested areas; 2) Insertion of instructional programs for the community; 3) Conducting workshops; 4) Encouraging people to look for ticks if they have walked through risky places, with immediate removal of ectoparasites; 5) Use of a questionnaire to assess the knowledge of health professionals about the diagnosis and treatment; 6) Use of clothes with insecticides/repellents and, mainly; 7) Use of repellents and barrier methods.

The review studies were quite diverse and mostly dealt with encouraging preventive behaviors in individuals living in and/or visiting areas at risk, so that they can contribute to an early medical diagnosis, in order to reduce the lethality of the disease.

In conjunction with these results, the ET planning was built, in which the principle of significant learning by discovery and reception ${ }^{(47-48)}$ was adopted as a reference. Regarding the discovery, the ET produced is unfinished so that the apprentices can reorganize the set of information to integrate it with their cognitive structures, transforming the construction and creating the desired final product. At reception, the ET was presented to the apprentices in a finished way, requiring only that they internalize the material, which becomes available to be used in the future, providing the freedom to integrate previous knowledge.

In this way, with the plan and script in hand, as well as with the selection of the content, the production of the Interactive Laboratory was carried out. The contents considered relevant were subdivided and organized into 6 (six) learning stations composed of problematic questions to stimulate reflection and curiosity, which questioned the following: What is SF?; How is it transmitted?; Signs and symptoms, Areas of risk, and How to prevent it? The stations will be presented below (Figure 1).

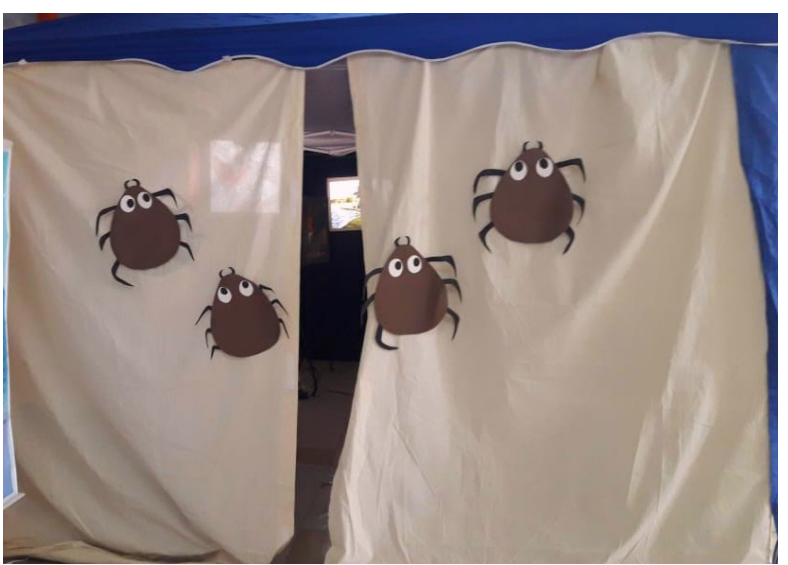

Figure 1 - Entrance to the Interactive Laboratory on spotted fever. Image copyright of the author. Ribeirão Preto, SP, Brazil, 2017 $1^{\text {st }}$ Station: Capybara? What does it represent in the problem? - This station had an illustrative model, representing a risk area, containing a lake, pasture, grass and capybaras. The purpose of this learning station is for the participant to be able to recognize an area at risk for contracting the SF disease, identifying the main animal (capybara) which hosts ticks that may be contaminated with the bacteria that causes SF (Figure $2 * A)$.

$2^{\text {nd }}$ Station: Star Tick or Micuim? - At this station, the participant watches a video that portrays the moment when a person is crossing a risky area and is bitten by ticks. Then, through an animation, the video shows the process in which the parasite sucks the host's blood and regurgitates saliva, which contains the bacteria that causes SF, infecting man. Printed and laminated images were also displayed at this station, showing the evolutionary phases of ticks. The purpose of this learning station is for the participant to be able to understand who is the causative and transmitting agent of the disease, in addition to visualizing the dynamics of the infestation (Figure $2^{+} \mathrm{B}$ ).

$3^{\text {rd }}$ Station: Smart housing! - To bring excitement and greater reality to the activity, this station contained a terrarium, composed of a seedling of grass planted in a pot and live ticks (nymphs). The purpose of this learning station is for the participant to be able to identify live ticks at the tip of the grass, recognizing how ticks are found in the environment (Figure $2^{\ddagger} \mathrm{C}$ ).

$4^{\text {th }}$ Station: Risk booth, stay tuned! - The "Senses Booth" was a resource designed for the participant to have the feeling of being in an area at risk for SF infection. Inside this booth, artificial grass was placed on the floor, in which Styrofoam ticks painted with fluorescent paint were adhered. When the participants entered the booth, an automatic movement control switched on a black light which induced flowering in the ticks. The participants also feel the grass brush their legs, which stimulates the senses. The purpose of this learning station is to offer an experience to the participants, simulating the entry into an area of risk, articulating in a practical way information covered in previous stations (Figure $3^{*} A$ ).

$5^{\text {th }}$ Station: Stay informed, avoid ticks! - Seeking to show areas at risk, prevention, and signs of initial SF symptoms, this station exhibited high definition images in illuminated cubes made of canvas and wood, where each side of the cube showed a different image. In this station, the existence of a health team on the Campus was informed, which, in addition to notifying human parasitism due to ticks for environmental and epidemiological surveillance, guides and directs affected people for medical follow-up. The purpose of this learning station is for the participant to be able to 
recognize the signs and symptoms of SF and the types of prevention, in addition to reviewing the knowledge previously presented (Figure $3^{+} \mathrm{B}$ ).

$6^{\text {th }}$ Station: What should I do if I find a tick on me? To provide a more realistic learning experience, in this station, the participants had the opportunity to remove artificial ticks attached to a human silicone arm with tweezers, so that they could experience and simulate their removal. Still at this station, printed and laminated images were displayed, demonstrating the correct way to remove ticks. The purpose of this learning station is for the participant to know the correct way to remove ticks from the human body, so that tick fragments are not left inside the skin (Figure $3^{\ddagger} C$ ).

To disseminate the interactive laboratory to the population, a canvas panel was installed, containing information about the location, date, and time of the activity, as well as a QR code (2D barcode), which can be recognized by cell phones (smartphones), notebooks, and tablets, in order to provide access to a link ${ }^{(49)}$ on the Internet that promoted access to an informative text prepared by our research team, called "Spotted Fever - a disease transmitted by ticks", also available on the website of the Mayoralty of the USP Campus in Ribeirão Preto (Prefeitura do Campus USP de Ribeirão Preto, PUSP - RP) ${ }^{(50)}$.
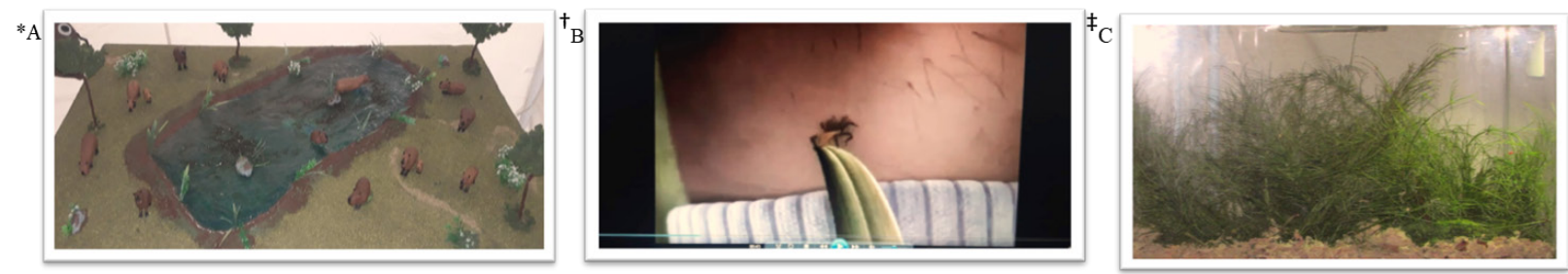

${ }^{*} \mathrm{~A}=$ Illustrative model of the $1^{\text {st }}$ Station. Image copyright by the author; ${ }^{+} \mathrm{B}=$ Video ${ }^{1}$ of the $2^{\text {nd }}$ Station; ${ }^{\ddagger} \mathrm{C}=$ Terrarium arranged with live ticks from the $3^{\text {rd }}$ season. Image copyright by the author

Figure 2 - Learning Stations. Ribeirão Preto, SP, Brazil, 2017
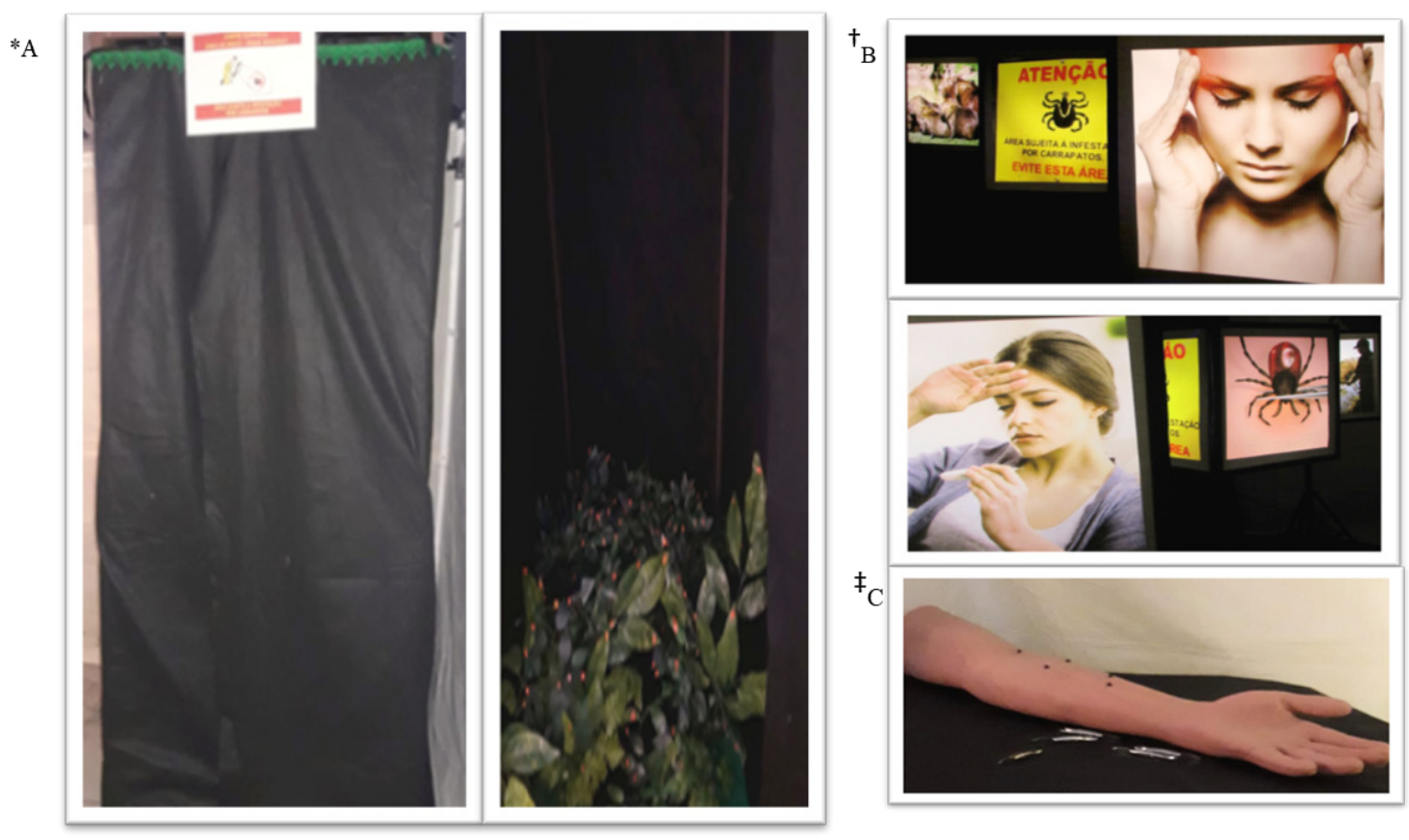

$* A=4^{\text {th }}$ station's sensory booth. Image copyright by the author; ${ }^{+} B=5^{\text {th }}$ station illuminated cubes ${ }^{2} ;{ }^{*} C=$ Silicone arm with artificial ticks from the $6^{\text {th }}$ station. Image copyright of the author.

Figure 3 - Learning Stations. Ribeirão Preto, SP, Brazil, 2017

\footnotetext{
${ }^{1}$ Source: Baxter BioScience. Baxter Healthcare Tick Animation. [Video]. Heidelberg (GER): Baxter Studiosoi; 2005 [cited Nov 28, 2019 ]. Available from: https://www. youtube.com/watch?v=WpOyWesQtgc

2 Source: Santa Paula Hospital. National Day to Combat Cephalea. [Internet]. São Paulo; 2018 [cited Nov 28 ${ }^{\text {th }}, 2019$ ]. Available from: https://www. santapaula.com.br/dia-nacional-de-combate-a-cefaleia/; Febre alta: tudo que você precisa saber sobre o assunto. [Internet]. São Paulo; 2017 [cited Nov $\left.28^{\text {th }}, 2019\right]$. Available from: https://blog.drconsulta.com/febre-alta-tudo-que-voce-precisa-saber-sobre-o-assunto/
} 
The interactive laboratory on SF sought to create an innovative environment by presenting six learning stations, with content contextualized in an increasing sequence of deepening. Furthermore, when participating in the ET, the apprentices can review the same topic as many times as they deem necessary, in addition to using the time they consider necessary. For this, the laboratory used potentially significant materials to interact in a nonarbitrary way with the individual's previous experience, offering options of modalities and strategies, in order to contribute to the teaching-learning process.

Throughout the course of the activity, a supervisor was present, acting as an orientator, stimulator, and evaluator of learning, assisting the participants in the task of formulating and reformulating concepts, activating their previous knowledge, and articulating this knowledge with new information.
The next stage of the study was the review and validation of the ET by specialists (judges) in the field of biology and education (appearance and content validation), as well as by representatives of the target population (semantic validation).

The panel of judges who participated in the appearance and content validation included 6 (six) women (66.75\%) and 3 (three) men (33.3\%), 7 (seven) of whom studied at a state institution (77.8\%) and 2 (two) at a private institution (22.2\%). All the judges reported having a Master's degree, 6 (six) of them also reported having a PhD degree (66.7\%) and 6 (six) cited having an internship and/or a specialization (66.7\%). Of the 9 (nine) judges, 7 (seven) $(77.8 \%$ ) work at the USP and 2 (two) (22.2\%) at another institution.

The judges' answers regarding the appearance and content validation for each of the items assessed in relation to the educational technology are shown in Table 1.

Table 1 - Distribution of the judges' answers in the validation of the instrument's appearance and content for each question presented according to the Likert scale. Ribeirão Preto, SP, Brazil, 2017

\begin{tabular}{|c|c|c|c|c|c|c|c|c|c|c|}
\hline Questions & $J^{* 1}$ & $\mathrm{~J} * 2$ & $\mathrm{~J} * 3$ & $\mathrm{~J} * 4$ & $J * 5$ & $J^{*} 6$ & $J * 7$ & $\mathbf{J} \times 8$ & $J * 9$ & $\mathrm{CVI}^{\dagger}$ \\
\hline Are the stations organized? & 5 & 5 & 5 & 5 & 5 & 5 & 5 & 5 & 5 & 1.00 \\
\hline Are the illustrations clear? & 5 & 5 & 5 & 5 & 5 & 5 & 5 & 5 & 5 & 1.00 \\
\hline $\begin{array}{l}\text { Do the illustrations help } \\
\text { to expand the content? }\end{array}$ & 5 & 5 & 5 & 5 & 5 & 5 & 5 & 5 & 5 & 1.00 \\
\hline $\begin{array}{l}\text { Is content presentation } \\
\text { coherent? }\end{array}$ & 5 & 5 & 5 & 5 & 5 & 5 & 5 & 5 & 5 & 1.00 \\
\hline $\begin{array}{l}\text { Is the instructional sequence } \\
\text { appealing and logical? }\end{array}$ & 5 & 5 & 5 & 5 & 5 & 5 & 5 & 5 & 5 & 1.00 \\
\hline $\begin{array}{l}\text { Does the activity } \\
\text { encourage interaction? }\end{array}$ & 4 & 5 & 5 & 5 & 5 & 4 & 5 & 5 & 5 & 1.00 \\
\hline $\begin{array}{l}\text { Is the size of the } \\
\text { content adequate? }\end{array}$ & 4 & 4 & 5 & 5 & 5 & 4 & 4 & 5 & 5 & 1.00 \\
\hline $\begin{array}{l}\text { Is the writing in } \\
\text { a sociable style? }\end{array}$ & 3 & 5 & 5 & 5 & 5 & 4 & 5 & 3 & 4 & 0.78 \\
\hline $\begin{array}{l}\text { Is any technical } \\
\text { jargon included? }\end{array}$ & 3 & 5 & 4 & 5 & 5 & 5 & 5 & 4 & 5 & 0.89 \\
\hline $\begin{array}{l}\text { Is the text vivid and } \\
\text { interesting? Is the } \\
\text { tone friendly? }\end{array}$ & 3 & 5 & 4 & 5 & 5 & 5 & 5 & 3 & 5 & 0.78 \\
\hline Is the text clear? & 4 & 5 & 5 & 5 & 5 & 4 & 5 & 4 & 5 & 1.00 \\
\hline Objectivity & 4 & 5 & 5 & 5 & 5 & 5 & 5 & 5 & 5 & 1.00 \\
\hline Scope & 4 & 5 & 4 & 5 & 4 & 5 & 5 & 5 & 5 & 1.00 \\
\hline Updating & 5 & 5 & 4 & 5 & 5 & 5 & 5 & 5 & 5 & 1.00 \\
\hline Vocabulary & 4 & 5 & 5 & 5 & 5 & 4 & 4 & 5 & 5 & 1.00 \\
\hline Clarity of the content & 4 & 5 & 5 & 5 & 5 & 4 & 5 & 5 & 5 & 1.00 \\
\hline $\begin{array}{l}\text { Content presentation } \\
\text { in each station }\end{array}$ & 4 & 5 & 4 & 5 & 5 & 4 & 5 & 5 & 5 & 1.00 \\
\hline Instructional sequence & 5 & 5 & 4 & 5 & 5 & 5 & 5 & 5 & 5 & 1.00 \\
\hline Objectivity & 5 & 5 & 5 & 5 & 5 & 5 & 5 & 5 & 5 & 1.00 \\
\hline Scope & 5 & 5 & 4 & 5 & 5 & 5 & 5 & 5 & 5 & 1.00 \\
\hline Updating & 5 & 5 & 4 & 5 & 5 & 5 & 5 & 5 & 5 & 1.00 \\
\hline Vocabulary & 4 & 5 & 5 & 5 & 5 & 4 & 5 & 4 & 5 & 1.00 \\
\hline Clarity of the content & 5 & 5 & 5 & 5 & 5 & 4 & 5 & 4 & 5 & 1.00 \\
\hline
\end{tabular}

*J = Judge; ${ }^{+} \mathrm{CVI}=$ Content Validity Index

As can be seen, the vast majority of the items had a CVI over 0.8 , meaning that there is great agreement between the judges. Only in 2 (two) items, "Is the writing in a sociable style?" and "Is the text 
vivid and interesting? Is the tone friendly?", the CVI was below 0.8 . Thus, 2 (two) judges indicated that they partially agreed, recording comments and suggestions: As the activity is not intended only for students in the health area, I suggest "popularizing" the language a little, since in some stations the content is written in a very scientific way which can impair learning for the participant who is from another course (Judge 1); In the video that the text is ok, it is more colloquial. However, in the printed version there are scientific terms and minor grammar errors that need to be corrected if it is to be disseminated in any environment (Judge 2).

In view of the judges' answers, we consider it pertinent to carry out a review of the content, making it more accessible to the population. For this purpose, the technical terms contained in the activity were removed, namely: cephalea and myalgia, in this way we were able to reduce the use of technical jargon, although this item had a CVI over 0.80

In the general impression semantic validation stage, all the participants considered the interactive laboratory as "very good" $(100 \%), 87.5 \%$ referred to ease of understanding, and $100 \%$ considered the stations to be important for SF knowledge. No participant suggested changing and/or adding anything to the learning stations.

In the specific semantic validation, where the content of each learning station was assessed separately, all the participants (100\%) in Group A considered the content of the stations clear and coherent. In Group B (students from the Pedagogy course), $25 \%$ of the participants had difficulty understanding the content of the $5^{\text {th }}$ learning station, which refers to the signs and symptoms of the disease. This result corroborates the judges' appreciation in the appearance and content validation, which guided the substitution of the words cephalea for headache and myalgia for muscle pain.

The vast majority of the participants in the semantic validation considered that the content of the learning stations was adequate to encourage health prevention and SF control practices, which indicates that the laboratory must have good acceptance and understanding by the target population, eliminating the need for major changes.

Taken together, the validation stages showed that the interactive laboratory on SF had clear and concise information that meets the needs of the target audience; thus, scientific proof was provided which supported the implementation of the ET.

\section{Discussion}

This research developed and validated an ET called "Interactive Laboratory on Spotted Fever" for the population of the USP Campus of Ribeirão Preto, considered a risk area for contracting the disease. The methodological study began with an assessment of the context where the ET will be applied and a description of the knowledge gaps on the topic, configuring the diagnostic analysis. Later, it endorsed the importance of instructional planning, its didactic design, and validation, in order to meet the learning needs, based on the theory of significant learning(27).

The Ausubel framework was chosen for providing the individual inserted in the teaching-learning process, the development of a new concept based on previous knowledge. Some authors have used this framework for the development of ETs aimed at the adult audience, and this has proved to be appropriate to contribute to changes in knowledge in a significant way ${ }^{(51-52)}$.

When analyzing ETs developed in countries like the United States(53), Spain ${ }^{(54)}$, Colombia(55), Chile(56), Venezuela(57), and $\operatorname{Brazil}^{(24,35,58-60)}$, it was possible to understand that the best results are directly associated with the interaction that these resources provide. That is, these studies show that it is essential to consider the users' prior knowledge and doubts in the elaboration of ETs; to this is added the relationship between the quality of educational materials and the use of defined principles and types of elaboration ${ }^{(61-63)}$.

Accordingly, studies carried out in Brazil(64-65), Venezuela ${ }^{(66)}$, United States ${ }^{(67)}$, and Italy ${ }^{(68)}$ that worked with ETs obeying scientific criteria and seeking to know the target population, adopted strategies with the potential to gather modifying knowledge for the teaching-learning process.

The instructional planning of the current study was built in a systematic way to understand the scenario in which we were inserted, facilitating the choice of the approach and the type of action for the transformation of the practice and, consequently, of the reality, and trying to build a creative, consistent, and innovative design.

A number of methodological studies developed by Nursing reveal that creativity associated with scientific knowledge strengthens and expands health education, offering new ways of thinking, organizing and managing care, which provides an innovative environment for the production of knowledge, enabling the autonomy of the subjects and promoting quality of life(69-70).

However, in order for the ET to fulfill its objective, validation as a scientifically reliable product is essential, and it is also tested for its effectiveness and suitability for its application ${ }^{(69)}$. In fact, carrying out the validation of an educational resource is crucial for researchers and health professionals to be able to trust and evaluate whether it is convenient for a given population ${ }^{(23)}$.

A study that aimed to build and validate an ET in the form of a video for people and families who experience 
colostomy and cancer highlights the importance of validation by specialists, since an educational material, when well produced and validated, can really contribute to modifying the reality of the subjects for whom it is intended(69).

The use of appearance and content validation by specialists (judges) has been adopted by several researchers in ET assessments. Our work, employing this type of validation, obtained CVI values similar to those found in the literature $\mathrm{e}^{(64-65,69,71-74)}$.

Interestingly, the target audience (semantic validation) also satisfactorily evaluated the interactive laboratory on SF. In addition, the participants brought valuable contributions and did not go to great lengths to collaborate with the improvement of the technology. This validation pointed out confusing and little understandable passages, enabling them to be adjusted and become compatible with popular understanding. Thus, the agreement of the students in relation to the clarity of the interactive laboratory led to a greater probability that the technology would enable the multiplication of information and contribute more effectively to the training of laypeople on the subject ${ }^{(75)}$.

In fact, receiving suggestions and opinions favored the exchange of ideas based on the participants' daily experiences. The validated technology is not restricted to promoting knowledge about SF, it awakens new ideas in the learners, instigating their curiosity and provoking contextualized and pleasurable reflections involving their health and that of the community in controlling SF.

Therefore, it is worth noting that the elaboration of an ET is not an elementary task, it requires commitment and involvement of a multiprofessional team, from the initial phases of its project to its distribution to the end user(71).

As for the limitation of this study, we can mention the cost for the development of an ET, since there is a demand for third party service contracts and consumables. Therefore, fundraising must be taken into consideration before starting the contract.

The interactive laboratory produced made the most of human potential in the construction of knowledge, by proposing an integration of different ways of apprehending new knowledge, extrapolating the visual and auditory sensations. In addition, it added experiences that transport the apprentices to a scenario very close to the real one, causing feelings and driving attitudes, in order to awaken behavior changes.

Finally, it should be noted that creativity was one of the main pillars for this study, since the individual's holistic involvement in the teaching-learning process was valued, using the playful and the imaginary through sensory experiences. Still, the theoretical framework which was selected also contributed to the fact that creativity was the main element in the planning of the ET, although always under methodological rigor.

\section{Conclusion}

This methodological study, which produced and validated an ET for health education on SF, was based on the needs of people who frequent an area at risk for the disease. It is considered that the trajectory followed provides academic and scientific support to the product constructed and also contributes with pedagogical potential as a propositive ET with an interactive approach, an essential requirement to value meaningful learning.

The methodology used proved to be able to support the elaboration of an innovative ET, which can instrumentalize the elaboration of other ETs, as well as sensitize health professionals, educators, and researchers for the production and validation of new ETs, both in this theme and in any another that involves health education actions.

Finally, developing an interactive laboratory on SF based on a methodological study can contribute to the empowerment of the population, favoring changes in attitudes. Thus, this work collaborates with the health promotion policy in face of the epidemiological and environmental surveillance actions for SF identified by the Ministry of Health in Brazil.

\section{Acknowledgments}

We thank Professor Claudia Benedita dos Santos for her kind assistance and support in this study and the DISABKIDS ${ }^{\circ}$ Brasil group for availing the semantic validation forms.

\section{References}

1. Montenegro DC, Bitencourth K, Oliveira SV, Borsoi AP, Cardoso KM, Sousa MSB, et al. Spotted Fever: Epidemiology and Vector-Rickettsia-Host Relationship in Rio de Janeiro State. Front Microbiol. 2017 Mar 30;8:505. doi: 10.3389/fmicb.2017.00505

2. Frang R, Blanton LS, Walker DH. Rickettsiae as emerging infectious agents. Clin Lab Med. 2017 Jun;37(2):383-400. doi: 10.1016/j.cll.2017.01.009

3. Shimizu K, Isozumi R, Takami K, Kimata I, Shiokawa K, Yoshimatsu $\mathrm{K}$, et al. Evidence of infection with Leptospira interrogans and spotted fever group rickettsiae among rodents in an urban area of Osaka City, Japan. J Vet Med Sci. 2017 Jul 19;79(7):1261-3. doi: 10.1292/jvms.17-0067 4. Heglasová I, Víchová B, Kraljik J, Mošanský L, Miklisová D, Stanko M. Molecular evidence and diversity of the spotted-fever group Rickettsia spp. in small mammals from natural, suburban and urban 
areas of Eastern Slovakia. Ticks Tick-borne Dis. 2018 Sep;9(6):1400-6. doi: 10.1016/j.ttbdis.2018.06.011

5. Martínez-Caballero A, Moreno B, Gonzáles C, Martínez G, Adames M, Pachar JV, et al. Descriptions of two new cases of Rocky Mountain spotted fever in Panama, and coincident infection with Rickettsia rickettsii in Rhipicephalus sanguineus s.l. in an urban locality of Panama City, Panama. Epidemiol Infect. 2018 May;146(7):875-8. doi: 10.1017/S0950268818000730 6. Martins MEP, Brito WMED, Labruna MB, Moraes Filho J, Sousa-Martins KC, Vieira RP. Epidemiological survey of supposed spotted fever outbreak. Cienc Anim Bras. 2016 Jul./Sep;17(3):459-71. doi: 10.1590/1089$6891 v 17 i 334947$

7. Sousa OMF, Tourinho BD, Leite PL, Souza PB, Dure AIL, Veloso I, et al. Spotted fever in the Metropolitan Region of Belo Horizonte, Minas Gerais - Brazil: description of cases and probable environments of infection, 2017. J Health Biol. Sci. 2020;8(1):1-6. doi: 10.12662/23173076jhbs.v8i1.2651.p1-6.2020

8. Ministério da Saúde (BR). Sistema de Informação de Agravos de Notificação - SINAN. Febre maculosa: casos confirmados notificados no Sistema de Informação de Agravos e Notificação. [Internet]. Brasília: DATASUS; 2019 [cited May 27, 2019]. Available from: http:// tabnet.datasus.gov.br/cgi/deftohtm.exe?sinannet/cnv/ febremaculosabr.def

9. Secretaria de Estado da Saúde (São Paulo). Dados estatísticos: febre maculosa. [Internet]. São Paulo: Centro de Vigilância Epidemiológica - prof. Alexandre Vranjac; 2019 [cited May 27, 2019]. Available from: http://www.saude.sp.gov.br/cve-centro-de-vigilanciaepidemiologica-prof.-alexandre-vranjac/oldzoonoses/ febre-maculosa/dados-estatisticos

10. Armitano RI, Guillemi E, Escalada V, Govedi F, Lopez JL, Farber M, et al. Spotted fever in Argentina. Description of two clinical cases. Rev. Argent Microbiol. 2019 Mar 28;S0325-7541(19):30001-X. doi: 10.1016/j. ram.2018.11.001

11. Vélez JCQ, Aguirre-Acevedo DC, Rodas JD, Arboleda M, Troyo A, Aguilar FV, et al. Epidemiological characterization of incident cases of Rickettsia infection in rural areas of Urabá region, Colombia. PLOS Negl Trop Dis. 2018 Oct 31;12(10):1-16. doi: 10.1371/journal.pntd.0006911

12. Oliveira SV, Guimarães JN, Reckziegel GC, Neves BMC, Araújo-Vilges KM, Fonseca LX, et al. An update on the epidemiological situation of spotted fever in Brazil. J Venom Anim Toxins Incl.Trop Dis. 2016;22:22. doi: 10.1186/s40409-016-0077-4

13. Costa GA, Carvalho AL, Teixeira DC. Spotted fever: update. Rev Med Minas Gerais. 2016;26 (Supl 6):S61-S64. doi: 10.5935/2238-3182.20160059
14. Straily A, Drexler N, Cruz-Loustaunau D, Paddock CD, Alvarez-Hernandez G. Notes from the Field: communitybased prevention of Rocky Mountain Spotted Fever Sonora, Mexico, 2016. MMWR Morb Mortal Wkly Rep. 2016 Nov 25;65(46):1302-3. doi: 10.15585/mmwr.mm6546a6 15. Binder AM, Nichols Heitman K, Drexler NA. Diagnostic Methods Used to Classify Confirmed and Probable Cases of Spotted Fever Rickettsioses - United States, 2010-2015. MMWR Morb Mortal Wkly Rep. 2019 Mar 15;68:243-6. doi: 10.15585/mmwr.mm6810a3External 16. Rosenberg R, Lindsey NP, Fischer M, Gregory CJ, Hinckley AF, Mead PS, et al. Vital Signs: Trends in Reported Vectorborne Disease Cases - United States and Territories, 2004-2016. MMWR Morb Mortal Wkly Rep. 2018 May 4;67:496-501. doi: 10.15585/mmwr. mm6717e1External

17. Oliveira SV, Caldas EP, Limongi JE, Gazeta GS. Knowledge and attitudes of prevention evaluation of spotted fever among health care professionals in Brazil. J Health Biol Sci. 2016;4(3):152-9. doi: 10.12662/23173076jhbs.v4i3.851.p152-159.2016

18. Oliveira SV, Pereira SVC, Pinna FV, Fonseca LX, Serra-Freire NM, Cardoso KM, et al. Surveillance of environments of spotted fever: exploring the quiet areas of Brazil. Rev Pan-Amaz Saúde. 2016 Sep;7(3):65-72. doi: 10.5123/S2176-62232016000300008

19. Soares AN, Souza V, Santos FBO, Carneiro ACLL, Gazzinelli MF. Health education device: reflections on educational practices in primary care and nursing training. Texto ContextoEnferm. 2017 Aug 17;26(3):e0260016. doi: http://dx.doi.org/10.1590/0104-07072017000260016 20. Ribeiro KG, Andrade LOM, Aguiar JB, Moreira AEMM, Frota $A C$. Education and health in a region under social vulnerability situation: breakthroughs and challenges for public policies. Interface (Botucatu). 2018;22(Supl.1):138798. doi: 10.1590/1807-57622017.0419

21. Silva JP, Gonçalves MFC, Andrade LS, Monteiro EMLM, Silva MAI. Promoción de la salud en la educación básica: percepciones de los estudiantes de pregrado de enfermería. Rev Gaúcha Enferm. 2018 Set 3;39: e2017-37. doi: 10.1590/1983-1447.2018.2017-0237

22. Kessler M, Thumé E, Duro SMS, Tomasi E, Siqueira FCV, Silveira DS, et al. Health education and promotion actions among teams of the National Primary Care Access and Quality Improvement Program, Rio Grande do Sul state, Brazil. Epidemiol Serv Saúde. 2018 Jun 28;27(2):e2017389. doi: 10.5123/S167949742018000200019

23. Silva DML, Carreiro FA, Mello R. Educational technologies in nursing assistance in health education: integrating review. Rev Enferm UFPE On Line. 2017 Feb;11(Supl. 2):1044-51. doi: 10.5205/reuol.1026391568-1-RV.1102sup201721 
24. Maniva SJCF, Carvalho ZMF, Gomes RKG, Carvalho REFL, Ximenes LB, Freitas CHA. Educational technologies for health education on stroke: an integrative review. Rev Bras Enferm. 2018 Apr 19;71(Suppl 4):1724-31. doi: 10.1590/0034-7167-2017-0041

25. Machado FC, Lima MFWP. The technology of educational use: an educational do in school everyday. Scientia Cum Industria. 2017;5(2):44-50. doi: 10.18226/ 23185279.v5iss2p44

26. Oudeyer PY, Gottlieb J, Lopes, M. Intrinsic motivation, curiosity, and learning. Prog Brain Res. 2016 Jul 29;229:257-84. doi: 10.1016/bs.pbr.2016.05.005

27. Ausubel DP. Learning by discovery: Rationale and mystique. NASSP Bulletin. 1961 Dec 1;45(269):18-58. doi: $10.1177 / 019263656104526904$

28. Ausubel DP. In defense of verbal learning. Educ Theory. 1961 Jan;11(1):15-25. doi: 10.1111/j.17415446.1961.tb00038

29. Lobiondo-Wood G, Haber J. Pesquisa em Enfermagem: métodos, avaliação crítica e utilização. $4^{a}$ ed. Rio de Janeiro: Guanabara-Koogan; 2001.

30. Abreu D. Produção de material didático para EaD. Paraná: Editora da UFPR; 2010.

31. Jesus AA, Bragagnollo GR, Ferreira BR. Assessing knowledge about spotted fever for users of the campus of Ribeirão Preto - USP through an educational intervention. Rev Uningá. [Internet]. 2016 Oct-Dec [cited May 29, 2020];28(3):142-9. Available from: http://revista.uninga. br/index.php/uningareviews/article/view/1884/1482

32. Barros Leal R. Planejamento de ensino: peculiaridades significativas. RIEOEI. [Internet]. 2005 [cited May 29, 2020];37(3):1. doi: https://doi.org/10.35362/rie3732705 33. Alvim MB, Reis AV, Gutmacher L, Silva ACM. Sensory laboratory: a proposal for activating the body. Interface (Botucatu). 2019;23:e180367. doi: 10.1590/ interface. 180367

34. Kerr D, Ratcliff J, Tabb L, Walter R. Undergraduate nursing student perceptions of directed self-guidance in a learning laboratory: an educational strategy to enhance confidence and workplace readiness. Nurse Educ Pract. 2020;24:e102669. doi: 10.1016/j.nepr.2019.102669

35. Franco LLMM, Martorell LB, Reis LBM, Tavares GG. Thematic sensory station: pedagogical resource for training the dentist in the production of health care. Rev ABENO. 2017;17(4):193-202. doi: 10.30979/ rev.abeno.v17i4.519

36. Nascimento FEM, Silva DG. Technology-Mediated Education: innovations in the teaching and learning process an integrative review. Abakos. 2018 May;6(2):72-91. doi: 10.5752/P.2316-9451.2018v6n2p72-91

37. Pasquali L. Testes referentes a construto: teoria e modelo de construção. In: Pasquali L. Instrumentação psicológica: fundamentos e práticas. Porto Alegre: Artmed; 2010. p. 165-98.

38. Disabkids Group. Translation and validation procedure. Guidelines and documentation form. [Internet]. Leiden: The DISABKIDS Group. 2004 [cited Mar 2, 2018]. Available from: https://www.disabkids. org/licensing-and-use/validation-guidelines

39. Conselho Nacional de Desenvolvimento Científico e Tecnológico. [Internet]. 2016. Available from: http://lattes.cnpq.br/.

40. Zem-Mascarenhas SH, Cassiani SHB. Children and medication: an educational software for pediatric nursing education. Rev Bras Enferm. 2000;53(4): 499-507. doi: 10.1590/S0034-71672000000400003

41. Disabkids Group. Pilot Test Manual. Leiden: The DISABKIDS Group; 2002.

42. Fuzissaki MA, Santos CB, Almeida AM, Gozzo TO, Clapis MJ. Semantic validation of an instrument to identify the nursing practice in the management of radiodermatitis. Rev Eletr Enf. 2016;18:e1142. doi: $10.5216 /$ ree.v18.35164

43. Reina-Gamba NC, Richart-Martinez M, Cabrero-Garcia J. Cross-cultural validation of the "DISABKIDS" questionnaire for quality of life among Colombian children with chronic diseases. Rev. Latino-Am. Enfermagem. 2018;26:e3020. doi: $10.1590 / 1518-8345.2378 .3020$

44. Coluci MZO, Alexandre NMC, Milani D. Construction of measurement instruments in the area of health. Ciênc Saúde Coletiva. 2015;20(3):925-36. doi: 10.1590/141381232015203.04332013

45. International Business Machines Corporation (IBM). Statistical Package for the Social Sciences (SPSS). Versão 17.0. [S.I]: IBM; 2008. CD-ROM.

46. Brasil. Resolução 466, de 12 de dezembro de 2012. Dispõe sobre diretrizes e normas regulamentadoras de pesquisas envolvendo seres humanos. [Internet]. Diário Oficial [da] República Federativa do Brasil. Brasília, 13 jun 2012 [Acesso 20 jan 2018]. Disponível em: https://bvsms.saude.gov.br/bvs/saudelegis/cns/2013/ res0466_12_12_2012.html

47. Ausubel DP. A aprendizagem significativa: a teoria de David Ausubel. São Paulo: Moraes; 2006.

48. Ausubel DP. Aquisição e retenção de conhecimentos: uma perspectiva cognitiva. Lisboa: Plátano; 2006. (Edições Técnicas)

49. Universidade de São Paulo. Prefeitura do Campus de Ribeirão Preto. Febre maculosa: uma doença transmitida por carrapatos. [Internet]. Ribeirão Preto: USP; 2017 [Acesso 2 mai 2019]. Disponível em: http:// www.prefeiturarp.usp.br/pages/vetores/cadastro/ FebreMaculosa.pdf

50. Universidade de São Paulo. Prefeitura do Campus de Ribeirão Preto. Relatório de atividades. [Internet]. 
2012 [Acesso 20 mai 2015]. Disponível em: http://www. prefeiturarp.usp.br/pages/relatativid/Relat\%C3\%B3rio\%20 de\%20Ativid ades\%20PUSP-RP\%202012.pdf

51. Góes FSN, Fonseca LMM, Camargo RAA, Hara CYN, Gobbi JD, Stabile AM. Developing a digital learning environment in nursing professional education. Cienc Enferm. [Internet]. 2015 [cited May 29, 2020];XXI(1):81-90. Available from: https://www.redalyc.org/pdf/3704/370441818008.pdf

52. Carvalho LR, Domingues NA, Zem-Mascarenhas SH. Development of digital educational technology about minimally invasive intracranial pressure monitoring. Texto Contexto Enferm. 2017;26(4):e0830017. doi: 10.1590/0104-07072017000830017

53. Dumas RP, Vella MA, Hatchimonji JS, Ma L, Maher Z, Holena DN. Trauma video review utilization: a survey of practice in the United States. Am J Surg. 2020 Jan;219(1):49-53. doi: 10.1016/j.amjsurg.2019.08.025 54. Tur G, Marín VI, Carpenter J. Using twitter in higher education in Spain and the USA. Rev Comunicar. 2017 Apr 01;51(XXV):19-28. doi: 10.3916/C51-2017-02

55. Sanabria AGZ, Pava CNR, Torres MJH, López OLO, Castaño A. Educational intervention on Human Immunodeficiency Virus in the homeless community that attends a reception center in the city of Bogotá D.C. - Colombia. Nova. [Internet]. 2017 [cited Apr 1, 2020];15(28):11-7. Available from: http://www.scielo. org.co/scielo.php?script=sci_abstract\&pid=S179424702017000200011\&lng=en\&nrm=iso\&tlng=en

56. Encina C, Gallegos D, Ulloa A, Luman M, Moena $B$, Canales $T$, et al. Concordance between maternal perception and child's nutritional status before and after an educational intervention. Rev Chil Nutr. 2017;44(4): 318-24. doi: 10.4067/s0717-75182017000400318

57. Lucente R, Briceño M. Educational software as a tool for preschool teachers' formation in the promotion of oral health. Invest Postgrado. [Internet]. 2017 [cited May 26, 2019];32(1):9-32. Available from: https:// dialnet.unirioja.es/descarga/articulo/6430683.pdf

58. Landeiro MJL, Peres HHC, Martins TV. Evaluation of the educational technology "Caring for dependente people" by family caregivers in changes and transfers of patients and tube feeding. Rev. Latino-Am. Enfermagem. 2016;24:e2774. doi: 10.1590/1518-8345.0846.2774

59. Andrade IS, Castro RCMB, Moreira KAP, Santos CPRS, Fernandes AFC. Effects of technology on knowledge, attitude and practice of pregnant women for childbirth. Rev Rene. 2019;20:e41341. doi: 10.15253/21756783.20192041341

60. Bragagnollo GR, Toledo PCG, Morero JAP, Scarpini NAM, Ferreira BR. Evaluation of an educational program on intestinal parasites implemented in a community school teacher by look. [Internet]. Rev. Uningá. 2017 Jan/Mar [cited Jun 26, 2018];51(1):12-21. Available from: http:// revista.uninga.br/index.php/uninga/article/view/1343

61. Veraszto EV, Amaral SF, Camargo JTF, Souza KI, Barreto G. Construction of interactivity indicators for collaborative learning. Rev Int Tecnol Educ. [Internet]. 2016 [cited May 26, 2019];3(1):43-51. Available from: https:// journals.eagora.org/revEDUTECH/article/view/283/395 62. Bonilla MHS, Silva MCCC, Machado TA. Digital Technologies and visual impairment: the contribuition of ICT to pedagogical practices in the context of the Brazilian Law for the inclusion of persons with disability. Rev Pesq Qualitativa. [Internet] 2018 Dec [cited May 26, 2019];6(12):412-25. Available from: https://editora. sepq.org.br/index.php/rpq/article/view/236/128

63. Cruz GCV, Vasconcelos MGF, Maniva SJCF, Carvalho REFL. Construction and validation of an educational technology on human papilomavirus vaccine for adolescentes. Esc Anna Nery. 2019;23(3):e20190050. doi: 10.1590/2177-9465-ean-2019-0050

64. Benevides JL, Coutinho JFV, Pascoal LC, Joventino ES, Martins MC, Gubert FA, et al. Development and validation of educational technology for venous ulcer care. Rev Esc Enferm USP. 2016 Mar/Apr;50(2):309-16. doi: 10.1590/S0080-623420160000200018

65. Moura IH, Silva AFR, Rocha AESH, Lima LHO, Moreira TMM, Silva ARV. Construction and validation of educational materials for the prevention of metabolic syndrome in adolescents. Rev. Latino-Am. Enfermagem. 2017;25:e2934. doi: 10.1590/1518-8345.2024.2934 66. Machado MSP, Sepúlveda GCT, Montoya MSR. Educational innovation and digital competencies: the case of OER in a private Venezuelan university. Int J Educ Technol High Educ. 2016;13:10. doi: 10.1186/ s41239-016-0006-1

67. Wang $H$, Singhal A. East los high: transmedia edutainment to promote the sexual and reproductive health of young Latina/o americans. Am J Public Health. 2016 Jun;106(6):1002-10. doi: 10.2105/AJPH.2016.303072 68. Gigantesco A, Palumbo G, Zadworna-Cieslak M, Cascavilla I, Del Re D, Kossakowska K, et al. An international study of middle school students' preferences about digital interactive education activities for promoting psychological well-being and mental health. Ann Ist Super Sanita. 2019 Apr-Jun;55(2):108-17. doi: 10.4415/ANN_19_02_02

69. Rosa BVC, Girardon-Perlini NMO, Gamboa NSG, Nietsche EA, Beuter M, Dalmolin A. Development and validation of audiovisual educational technology for families and people with colostomy by cancer. Texto Contexto Enferm. [Internet]. 2019;28:e20180053. doi: 10.1590/1980-265X-TCE-2018-0053

70. Silva NF, Silva NCM, Ribeiro VS, Iunes DH, Carvalho EC. Construction and validation of an educational video on foot 
reflexology. Rev Eletr Enferm. [Internet]. 2017;19:a48. doi: https://doi.org/10.5216/ree.v19.44324

71. MagalhãesSS,ChavesEMC, QueirozMVO. Instructional design for nursing care to neonates with congenital heart defects. Texto Contexto Enferm. 2019;28:e20180054. doi: 10.1590/1980-265x-tce-2018-0054

72. Leite SS, Áfio ACE, Carvalho LV, Silva JM, Almeida PC, Pagliuca LMF. Construction and validation of an Educational Content Validation Instrument in Health. Rev Bras Enferm. [Internet]. 2018;71(Suppl 4):1635-41. doi: 10.1590/0034-7167-2017-0648

73. Jesus EB, Esteves AVF, Teixeira E, Medeiros HP, Nascimento $\mathrm{MH}$, Saboia VM. Validation of educational technology on phototherapy to guide family members of icteric neonates. Rev Enferm UERJ. 2018;26:e21789. doi: 10.12957/reuerj.2018.21789

74. Santos FC, Riner ME, Henriques SH. Brazilian questionnaire of competencies of oncology nurses: Construction and test of content validation. Int J Nurs Sci. 2019 Jun;6(3):288-93. doi: 10.1016/j.ijnss.2019.06.005 75. Galindo-Neto NM, Alexandre ACS, Barros LM, Sá GGM, Carvalho KM, Caetano JA. Creation and validation of an educational video for deaf people about cardiopulmonary resuscitation. Rev. Latino-Am. Enfermagem. 2019;27:e3130. doi: $10.1590 / 1518-8345.2765 .3130$ Creative Commons (CC BY).

This license lets others distribute, remix, tweak, and build upon your work, even commercially, as long as they credit you for the original creation. This is the most accommodating of licenses offered. Recommended for maximum dissemination and use of 